\title{
Spontaneous increase of transforming growth factor $\beta$ production by bronchoalveolar mononuclear cells of patients with systemic autoimmune diseases affecting the lung
}

\author{
Y Deguchi
}

\begin{abstract}
The spontaneous increase in the transcription of the transforming growth factor $\beta$ (TGF $\beta$ ) gene in bronchoalveolar mononuclear cells of patients with autoimmune diseases affecting the lung has been shown by northern blot assay and a nuclear run on transcription assay. Transcription of the TGF $\beta$ gene in bronchoalveolar mononuclear cells of patients with autoimmune diseases affecting the lung was increased 10 times compared with normal healthy subjects or patients with bronchial asthma as controls. This observation, confirmed by protein data, suggests that TGF $\beta$, a potent mitogen for fibroblasts, may be produced in bronchoalveolar mononuclear cells during an active immune response in such patients and may be involved in autoimmune related changes of the pathophysiology of cytokine networks when the lung is affected, such as in lung fibrosis.
\end{abstract}

Chronic pulmonary fibrosis can occur as a manifestation of systemic autoimmune diseases and is characterised by an increased activity of fibroblasts and the overproduction of extracellular matrix components. Researchers have directed their attention towards immunological abnormalities, ${ }^{1}$ but there are few data available on the mechanisms of how the lung is affected in systemic autoimmune diseases.

Transforming growth factor $\beta$ (TGF $\beta$ ) is a multifunctional regulator of cell growth and differentiation in vitro and in vivo. ${ }^{2}$ TGF $\beta$ is a powerful chemoattractant for monocytes and a

Table 1 Clinical and laboratory features of the patients with autoimmune diseases examined in this study

\begin{tabular}{|c|c|c|c|c|c|}
\hline \multirow{2}{*}{$\begin{array}{l}\text { Patient } \\
\text { No }\end{array}$} & \multirow[t]{2}{*}{ Sex } & \multirow{2}{*}{$\begin{array}{l}\text { Clinical } \\
\text { activity }^{*}\end{array}$} & \multirow{2}{*}{$\begin{array}{l}\text { Clinical } \\
\text { manifestationt }\end{array}$} & \multicolumn{2}{|c|}{ Autoantibodies } \\
\hline & & & & $A N F$ & AntiDNA \\
\hline $\begin{array}{l}\text { Patients } \\
1 \\
2 \\
3 \\
4\end{array}$ & $\begin{array}{l}S L E \\
\mathrm{~F} \\
\mathrm{~F} \\
\mathrm{~F} \\
\mathrm{M}\end{array}$ & $\begin{array}{l}\text { Very active } \\
\text { Active } \\
\text { Active } \\
\text { Very active }\end{array}$ & $\begin{array}{l}\text { P, Sk, R, N, A } \\
\text { P, Sk, R, F, A } \\
\text { P, Sk, O, H, A } \\
\text { P, Sk, R, O, A }\end{array}$ & $\begin{array}{l}2^{10} \\
2^{10} \\
2^{8} \\
2^{10}\end{array}$ & $\begin{array}{r}122 \\
64 \\
64 \\
122\end{array}$ \\
\hline $\begin{array}{l}\text { Patients } \\
1 \\
2 \\
3 \\
4 \\
5\end{array}$ & $\begin{array}{l}\text { progres } \\
\mathbf{F} \\
\mathbf{F} \\
\mathbf{F} \\
\mathbf{M} \\
\mathbf{M}\end{array}$ & $\begin{array}{l}\text { ve systemic sclerosis } \\
\text { Active } \\
\text { Active } \\
\text { Very active } \\
\text { Active } \\
\text { Active }\end{array}$ & $\begin{array}{l}\text { P, Sk, R } \\
\text { P, Sk, R } \\
\text { P, Sk, R } \\
\text { P, Sk, A } \\
\text { P, Sk, R, A }\end{array}$ & $\begin{array}{l}2^{6} \\
2^{4} \\
2^{4} \\
2^{4} \\
2^{4}\end{array}$ & $\begin{array}{r}32 \\
8 \\
64 \\
8 \\
64\end{array}$ \\
\hline
\end{tabular}

*Clinical activity was determined according to the University College Hospital/Middlesex criteria for systemic lupus erythematosus ${ }^{7}$ and clinical and pathological findings for scleroderma. ${ }^{8}$ tAbbreviations used: $\mathrm{S} \mathbf{k}=$ skin disorder; $\mathrm{R}=$ renal disorder; $\mathrm{P}=$ pulmonary disorder; $\mathrm{N}=$ neurological disorder; $\mathbf{H}=$ haematological disorder; $\mathbf{O}=$ oral ulcer; $\mathbf{A}=$ arthritis.

fTitre of antinuclear factor (ANF) is less than $2^{1}$ in normal subjects; antiDNA (antibodies to double stranded DNA is less than $10 \mathrm{U} / \mathrm{ml}$ in normal subjects.

$\mathrm{F}=$ female; $M=$ male. potent mitogen for fibroblasts, working with interleukin $1 .^{3}$ TGF $\beta$ also has a chemoattractant activity for fibroblasts and stimulates the growth of immature fibroblasts. ${ }^{45}$ TGF $\beta$ enhances the synthesis of collagen, fibronectin, and proteoglycans, but inhibits protease secretion..$^{56}$

In this context, to study the part that TGF $\beta$ plays when the lung is affected in systemic autoimmune diseases such as pulmonary fibrosis, we studied the transcriptional level of the TGF $\beta$ gene in bronchoalveolar mononuclear cells of such subjects by northern blot assay and a nuclear run on transcription assay. The spontaneous production of TGF $\beta$ by the bronchoalveolar mononuclear cells of these patients was also examined. The possible effects of TGF $\beta$ on the pathogenesis of lung disease in patients with systemic autoimmune diseases is discussed.

\section{Patients, materials, and methods}

\section{PATIENTS AND CONTROLS}

We examined four patients (three women and one man) with active systemic lupus erythematosus (SLE), and five patients (three women and two men) with scleroderma (progressive systemic sclerosis). All had lung disease, which was diagnosed by both chest radiographs and a pulmonary function test. All patients had received prednisolone or azathioprine, or both. All patients with SLE met the American Rheumatism Association criteria. ${ }^{7}$ The diagnosis of scleroderma was made clinically and by biopsy specimens. ${ }^{8}$ Table 1 shows the clinical and laboratory findings of these patients. We also examined three patients with bronchial asthma who had been receiving $20 \mathrm{mg}$ or more of prednisolone per day and five healthy volunteers from the laboratory or hospital staff who had no history of the use of any drugs known to affect immune functions.

\section{PREPARATION OF BRONCHOALVEOLAR} MONONUCLEAR CELLS

Bronchoalveolar lavage cells were obtained from these subjects. Bronchoalveolar mononuclear cells were obtained with the Ficoll-Paque method. The cells were suspended in RPMI 1640 medium (Bioproducts), layered on FicollPaque, and centrifuged at $1800 \mathrm{rev} / \mathrm{min}$ for 20 minutes. Bronchoalveolar mononuclear cells were collected from the interface and washed twice with RPMI 1640 medium. The cell population was $>97 \%$ viable (trypan blue exclusion). 
PREPARATION OF RNA AND NORTHERN BLOT ASSAY RNA was prepared from bronchoalveolar mononuclear cells by the guanidinium thiocyanate method as described previously. ${ }^{9}$ RNA was quantified spectrophotometrically at 260 $\mathrm{nm}$ and applied to $0.8 \%$ formaldehyde agarose gels. Samples were transferred onto nylon membranes (Pall) and heated under vacuum at $80^{\circ} \mathrm{C}$ for two hours. The filters were hybridised overnight at $45^{\circ} \mathrm{C}$ with ${ }^{32} \mathrm{P}$ labelled synthetic oligonucleotides ( 80 mer) specific for the human TGF $\beta$ gene or the $\beta$ actin gene. ${ }^{9}$ After washing in $1 \times$ SSC ( $150 \mathrm{mM}$ sodium chloride, $15 \mathrm{mM}$ sodium citrate) and $0 \cdot 1 \%$ sodium dodecyl sulphate at $48^{\circ} \mathrm{C}$, the filters were exposed to Kodak AR X Omat films at $-70^{\circ} \mathrm{C}$.

\section{NUCLEAR RUN ON TRANSCRIPTION ASSAY}

Nuclei were prepared from the cells by lysing in a solution which contained $10 \mathrm{mM}$ TRIS-HCl buffer (pH 7.5), $2 \mathrm{mM}$ magnesium chloride, $3 \mathrm{mM}$ calcium chloride, $5 \mathrm{mM}$ DTT, and $0.02 \%$ of NP40, with subsequent centrifugation through a $2 \mathrm{M}$ sucrose solution. Three million nuclei were suspended in $100 \mu$ of $50 \%$ glycerol solution with $50 \mathrm{mM}$ TRIS-HCl buffer ( $\mathrm{pH}$ $7 \cdot 5$ ), $5 \mathrm{mM}$ magnesium chloride, and $0.1 \mathrm{mM}$ EDTA. The suspension of nuclei was immediately mixed with an equal volume of buffer containing $0.2 \mathrm{M}$ potassium chloride, $5 \mathrm{mM}$ magnesium chloride, $5 \mathrm{mM}$ DTT, $1 \mathrm{mM}$ ATP, CTP, GTP, and 200 units of RNasin (ribonuclease inhibitor, 500 units, Amersham International). The preparation was then incubated at $28^{\circ} \mathrm{C}$ for 20 minutes after the addition of $1850 \mathrm{kBq}$ of UTP labelled with ${ }^{32} \mathrm{P}$ $\left(5.4 \times 10^{4} \mathrm{MBq} / \mathrm{ml}\right.$, Amersham). To the preparation were added sodium dodecyl sulphate and EDTA solution to a final concentration of $1 \%$ and $5 \mathrm{mmol} / \mathrm{l}$ respectively, followed by treatment with proteinase $\mathrm{K}(1 \mathrm{mg} / \mathrm{ml})$ at $42^{\circ} \mathrm{C}$ for 30 minutes. RNA was extracted with phenol and chloroform from the preparation and precipitated with ethanol. The pellet was resuspended in $1 \mathrm{ml}$ hybridisation buffer which contained $50 \%$ formamide, $0.75 \mathrm{M}$ sodium chloride, $0.5 \%$ sodium dodecyl sulphate, $2 \mathrm{mM}$ EDTA, $50 \mathrm{mM}$ HEPES (pH 7.0), one tenth dilution of Denhardt's solution and denatured salmon sperm DNA $(500 \mu \mathrm{g} / \mathrm{ml}){ }^{10}{ }^{11}$ Finally, the preparation was applied to the nitrocellulose filter onto which the synthetic oligonucleotides ( 80 mers) specific for the human TGF $\beta$ or $\beta$ actin gene had been dotted. ${ }^{11}$

After 24 hours incubation the filters were washed three times in $0.5 \times$ SSC and $0.1 \%$ sodium dodecyl sulphate at $45^{\circ} \mathrm{C}$, dried and exposed to $x$ ray film with an intensifying screen at $-70^{\circ} \mathrm{C}$. In all experiments, the hybridised dots were excised from the filter and directly counted with a $\beta$ counter. ${ }^{11}$

\section{PREPARATION OF BRONCHOALVEOLAR}

MONONUCLEAR CELLS CONDITIONED MEDIUM AND ASSAY FOR TGF $\beta$ ACTIVITY

To obtain the bronchoalveolar mononuclear cells conditioned medium, bronchoalveolar mononuclear cells from patients and healthy control subjects were cultured in RPMI 1640 medium supplemented with $10 \%$ fetal bovine serum at $37^{\circ} \mathrm{C}$ in a carbon dioxide incubator. After 24 hours of incubation, the supernatants were harvested and stored at $-20^{\circ} \mathrm{C}$ before assay. ${ }^{12}$ As most TGF $\beta$ is secreted in a latent form, the bronchoalveolar mononuclear cells conditioned medium was activated by acidification before the assay, using standard protocols, to examine the production of active TGF $\beta .^{12} 13$ Briefly, crude bronchoalveolar mononuclear cells conditioned medium was acidified with $10 \%(\mathrm{v} / \mathrm{v})$ of $1 \mathrm{M}$ hydrochloric acid and incubated at room temperature for 30 minutes. Equal amounts of $1 \mathrm{M}$ sodium hydroxide solution and 1 M HEPES ( $\mathrm{pH} \mathrm{7 \cdot 4)}$ were added for neutralisation. The inhibition of growth on porcine aortic endothelial cells was used to determine the TGF $\beta$ activity as described previously. ${ }^{1213}$ Porcine aortic endothelial cells were cultured in Ham's F12 medium containing $1 \%$ fetal bovine serum and antibiotics in 24 well tissue culture plates. After 24 hours, test samples were added and incubated for an additional 18 hours. $\left[{ }^{3} \mathrm{H}\right]$ Thymidine $(7 \cdot 4 \mathrm{kBq})$ was then added to the cells and incubated for another six hours. The ${ }^{3} \mathrm{H}$ radioactivity incorporated into the DNA was determined as described previously. ${ }^{12}$ 13 TGF $\beta$ was determined by comparison with standard curves using human platelet derived TGF $\beta 1$ (R \& D Systems, Minneapolis, MN, USA).

STATISTICAL ANALYSIS

Statistical analysis of the data was performed using Student's $t$ test.

\section{Results}

To determine whether TGF $\beta$ affects the pathogenesis of pulmonary fibrosis in autoimmune diseases, we initially examined the amount of TGF $\beta$ mRNA in the bronchoalveolar mononuclear cells of subjects with autoimmune diseases and pulmonary fibrosis, and in normal healthy controls. After the extraction of RNA from the cells, it was hybridised with the human TGF $\beta$ specific probe and the hybridised spots were counted with the $\beta$ counter. The $\beta$ actin probe was used as a control. Figure 1 shows representative results of the northern blot assay of TGF $\beta$ and $\beta$ actin. Increased amounts of TGF $\beta$ transcripts of normal size were detected in the bronchoalveolar mononuclear cells of patients with systemic autoimmune diseases affecting the lung, compared with controls in whom no or very low levels of TGF $\beta$ transcripts were detected. The amount of $\beta$ actin transcript in the two types of cells was not changed.

The increase in TGF $\beta$ mRNA could result from either altered synthesis or degradation. To determine the transcriptional level of the TGF $\beta$ gene, the nuclei were isolated from these cells and used for the nuclear run on transcriptional assay to determine the transcriptional level of the TGF $\beta$ gene. Figure 2 shows that spontaneous enhancement of the transcription of the TGF $\beta$ gene was found in bronchoalveolar mononuclear cells of patients with autoimmune diseases and lung disease compared with the 
bronchoalveolar mononuclear cells of control subjects. Figure 3 summarises the transcriptional level of the TGF $\beta$ gene by this assay. More than ten times the amount of TGF $\beta$ was found in the bronchoalveolar mononuclear cells of

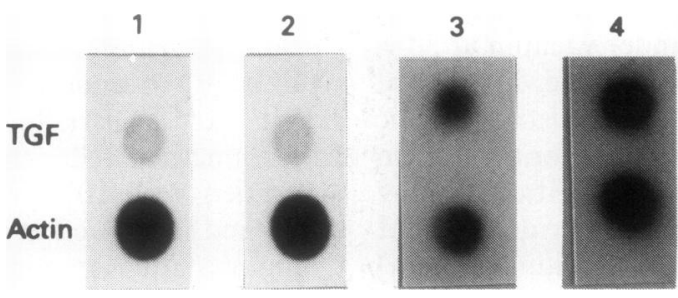

Figure 2 Representative nuclear run on transcription analysis of transforming growth factor $\beta(T G F)$ (36 hour exposure autoradiogram) and $\beta$ actin gene expression (24 hour exposure autoradiogram). Lanes 1 and 2 , bronchoalveolar mononuclear cells of a healthy subject and a patient with bronchial asthma; lanes 3 and 4 , bronchoalveolar mononuclear cells of patients with systemic lupus erythematosus and scleroderma.

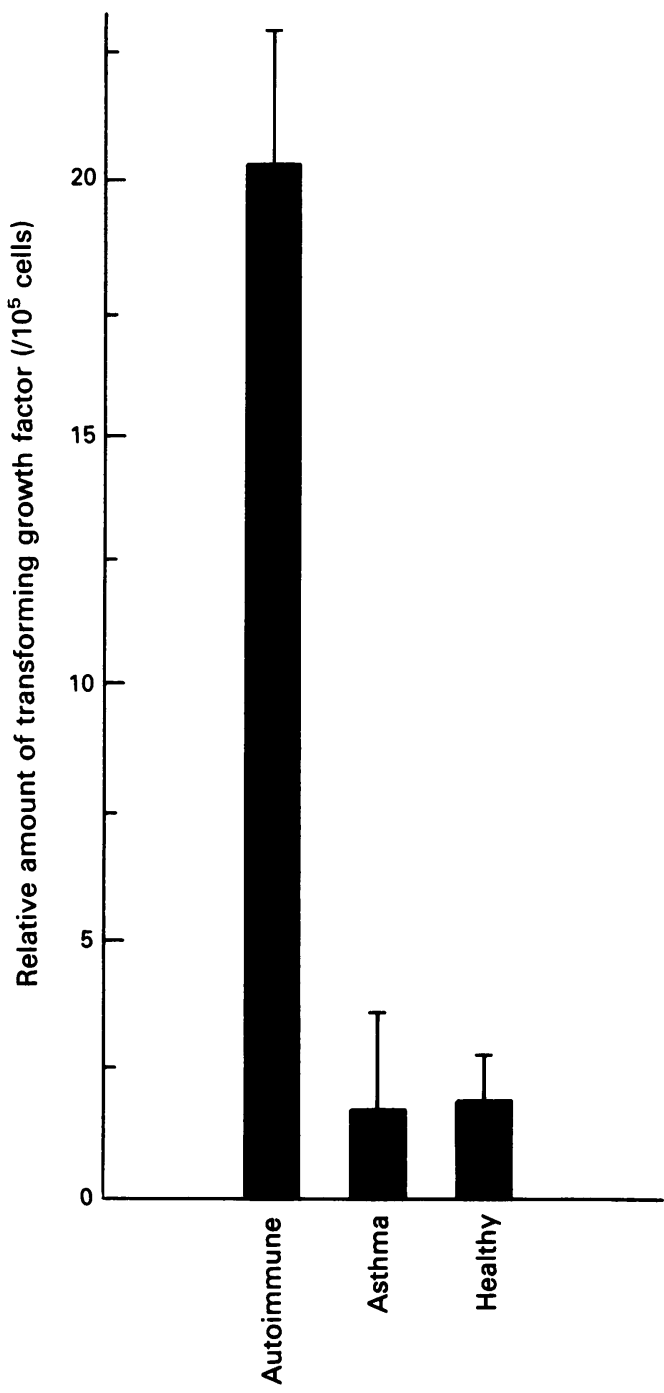

Figure 3 Summary of transforming growth factor $\beta$ gene transcriptional level in bronchoalveolar mononuclear cells of patients with systemic autoimmune diseases affecting the lung (autoimmune), patients with bronchial asthma (asthma), and normal healthy subjects (healthy). The relative amount (relative density per $10^{5}$ cells) of transforming growth factor $\beta$ gene transcription was determined by measuring hybridised dots in the nuclear run on transcription assay using a $\beta$ counter. Results are the mean value $(S D)$ of all cases studied.
Table 2 Levels of transforming growth factor $\beta$ production by bronchoalveolar mononuclear cells of patients with systemic autoimmune diseases affecting the lung. Results given are mean $(S D)$

\begin{tabular}{lr}
\hline $\begin{array}{l}\text { Sources of } \\
\text { broncheoalveolar mononuclear } \\
\text { cells }\end{array}$ & $T G F-\beta\left(p g / 10^{7}\right.$ cells $)$ \\
\hline $\begin{array}{l}\text { Normal healthy controls }(n=3) \\
\text { Patients with SLE }(n=3)\end{array}$ & $410(225)$ \\
Patients with scleroderma $(n=4)$ & $1288(453)$ \\
\hline
\end{tabular}

SLE $=$ systemic lupus erythematosus; TGF- $\beta=$ transforming growth factor $\beta$.

patients with autoimmune diseases and lung disease compared with controls. In the bronchoalveolar mononuclear cells of patients with autoimmune diseases, the spontaneous transcriptional level of the TGF $\beta$ gene increases and the increase in the total amount of TGF $\beta$ mRNA can result mainly from the enhanced transcription of this gene.

Finally, we examined the spontaneous production of TGF $\beta$ by the bronchoalveolar mononuclear cells of autoimmune patients with lung disease. Bronchoalveolar mononuclear cells conditioned medium was used for this assay. As most TGF $\beta$ is secreted in a latent form, the conditioned medium was activated by acidification before the assay. ${ }^{12}{ }^{13}$ Levels of TGF $\beta$ production by the bronchoalveolar mononuclear cells of three patients with SLE and lung disease, four scleroderma patients with lung disease, and three normal volunteers were studied and compared with standard curves using purified human TGF $\beta$ as described under materials and methods. The mean (SD) amount of TGF $\beta$ produced by normal bronchoalveolar mononuclear cells after 24 hours was $410(225) \mathrm{pg} / 10^{7}$ cells, that produced by patients with SLE and lung disease was 1288 (453), and that produced by patients with scleroderma and lung disease was 1417 (471) (table 2). Statistical analysis showed that there was a significant difference in TGF $\beta$ production between these patients. This increase in TGF $\beta$ production by bronchoalveolar mononuclear cells of patients with autoimmune disease agreed with the transcriptional enhancement data for bronchoalveolar mononuclear cells of patients with autoimmune diseases shown in figs 1-3.

\section{Discussion}

Lung disease, such as intractable lung fibrosis, is one of the major clinical problems in systemic autoimmune diseases. The mechanisms of how the lung is affected in these diseases are still unknown. It has been found that TGF $\beta$ mRNA is increased in the lungs of mice with bleomycin induced fibrosis in the early stages after bleomycin infusion, but not in the lungs of bleomycin resistant mice. ${ }^{14}$ The changes preceded increases in pulmonary fibronectin, procollagen $\alpha_{2}$ (I) and $\alpha_{1}$ (III) mRNA content and suggested that TGF $\beta$ may take part in the repair response. An increased amount of TGF $\beta$ mRNA in bronchoalveolar mononuclear cells of patients with autoimmune diseases and lung disease was found in this study. The increase in TGF $\beta$ transcripts could result from either altered 
synthesis or degradation. It was also shown by the nuclear run on assay that the transcriptional level of the TGF $\beta$ gene spontaneously increased in the bronchoalveolar mononuclear cells of subjects with autoimmune diseases and lung disease compared with controls, suggesting that increased TGF $\beta$ transcripts mainly resulted from this enhancement of transcription.

Abnormal gene expression is often caused by alterations in genomic DNA such as gene amplification or chromosomal translocations. We examined the possible alterations of the TGF $\beta$ gene in these cells by a Southern blot assay. We detected neither gene amplification nor detectable gene translocations (data not shown). We also used acidified bronchoalveolar mononuclear cells conditioned medium to examine active TGF $\beta$ production, as most of the TGF $\beta$ is secreted as a latent form. ${ }^{12}{ }^{13}$ The spontaneous increase in TGF $\beta$ production by bronchoalveolar mononuclear cells of patients with systemic autoimmune diseases and lung disease also agreed with the transcriptional data. It was shown that activated macrophages secreted TGF $\beta .{ }^{15}$ Our results support the view that activated macrophages recruited to an area of lung inflammation or injury are one of the major sources of TGF $\beta$, which affects the biochemistry of processes such as collagen synthesis, and the production of TGF $\beta$ from activated macrophages localised in the lung, may have a key role in pulmonary fibrosis in systemic autoimmune diseases. Tumour necrosis factor $\alpha$ has been shown to play a possible part, in the disease process of lung fibrosis. ${ }^{16}{ }^{17} \mathrm{~A}$ variety of cytokines have been shown to influence immunological reactions and pulmonary cells in vivo and in vitro. A further element of complexity results from the possibility that these mediators may influence each other. The results suggest that in diseases characterised by chronic pulmonary fibrosis, such as idiopathic pulmonary fibrosis, sarcoidosis, or Hamman-Rich syndrome, in which a continuous inflammatory response is evident, TGF $\beta$ production may be important in the pathogenesis or pathophysiology. Further studies on this are in progress.
We thank Dr S Kishimoto, Dr T Ohkubo and Dr J Curran for valuable discussions. This study was supported in part by grants from Ministry of Culture, Education and Science of the Japanese Government.

1 Jiminez S A. Cellular immune dysfunction and the pathogenesis of scleroderma. Semin Arthritis Rheum 1983; 13: 104-20.

2 Robert A B, Sporn M B. The transforming growth factor- $\beta$. In peptide growth factors and their receptors. Handbook of experimental pharmacology, Vol. 95. Heidelberg: Springer 1989: $1-155$.

3 Wahl S M, Hunt D A, Wakefield L M, et al. Transforming growth factor type beta induces monocyte chemotaxis and growth factor production. Proc Natl Acad Sci USA 1987; 84: 5788-92.

4 Postlethwaite A E, Keski E J, Moses H L, Kang A H. Stimulation of the chemotactic migration of human fibroblasts by transforming growth factor $\beta$. ₹ Exp Med 1987; 165: 251-62.

5 Fine A, Goldstein R H. The effects of transforming growth factor $\beta$ on cell proliferation and collagen formation by lung fibroblasts. F Biol Chem 1987; 262: 3897-905.

6 Ignotz R, Massague J. Transforming growth factor $\beta$ stimulates the expression of fibronectin and collagen and their incorporation into the extracellular matrix. F Biol Chem 1986; 261: 4337-41.

7 Tan E M, Cohen A S, Fries J F, et al. The 1982 revised criteria for the classification of systemic lupuserythematosus. Arthritis Rheum 1982; 25: 1271-7.

8 Barnett A J. Scleroderma (progressive systemic sclerosis): progress and course based on a personal series of 118 cases. Med f Aust 1978; 2: 129-34.

9 Deguchi Y, Negoro S, Kishimoto S. Age-related changes of heat shock protein gene transcription in human peripheral blood mononuclear cells. Biochem Biophys Res Commun 1988; 157: 580-4.

10 Marzluff W F, Huang R C C. Transcription and translation, a practical approach. Oxford: IRL Press, 1984: 1-130.

11 Reed J C, Tsujimoto Y, Alpers J D, Croce C M, Nowell P C. Regulation of bcl-2 protooncogene expression during normal human lymphocyte proliferation. Science 1987; 236: 1295-9.

12 Frolik C A, Wakefield L M, Smith D M, Sporn M B. Characterization of a membrane receptor for transforming growth factor $\beta$ in normal rat kidney fibroblasts. $\mathcal{f}$ Biol Chem 1984; 259: 10 995-11 000.

13 Miyazono K, Heldin C-H. Role for carbohydrate structures in TGF- $\beta 1$ latency. Nature 1989; 338: 158-60.

14 Khalil N, Bereznay O, Sporn M, Greenberg A H. Macrophage production of transforming growth factor $\beta$ and fibroblast collagen synthesis in chronic pulmonary inflammation. collagen synthesis in chronic

15 Assonian R K, Frolik B E, Stevenson H C, et al. Expression and secretion of type beta transforming growth factor by activated human macrophages. Proc Natl Acad Sci USA 1987; 84: 6020-5.

16 Piguet P F, Collart M A, Grau G E, Kapanci Y, Vassalli P. Tumor necrosis factor/cachectin plays a key role in bleomycin-induced pneumopathy and fibrosis. $\mathcal{F}$ Exp Med 1989; 170: 655-63.

17 Kindler V, Sappino A-P, Grau G E, Piguet P-F, Vassalli P. The inducing role of tumor necrosis factor in the development of bacterial granulomas during BCG infection. Cell 1989; 56: 731-40. 